\title{
Abbreviations used in the text
}

\begin{tabular}{ll} 
AA & Auswärtiges Amt [German Foreign Office] \\
AGP & Analysis of German Propaganda \\
BBC & British Broadcasting Corporation \\
BBC DD & BBC Daily Digest of Foreign (World) Broadcasts \\
BBC MR & BBC Monitoring Report \\
BBC WAC & BBC Written Archives Centre \\
BIPO & British Institute of Public Opinion \\
BREM & Station Bremen \\
BRES & Station Breslau \\
CAL & Station Calais \\
COLOG & Station Cologne \\
CPM & Christian Peace Movement \\
DES & Die Deutschen Europasender \\
DEUT & Deutschlandsender \\
DGP & Development of German Propaganda \\
DPP & [British] Director of Public Prosecutions \\
DÜS & Die Deutschen Überseesender \\
FBIS & [US] Foreign Broadcast Intelligence Service \\
FCC & [US] Federal Communications Commission \\
FO & [British] Foreign Office \\
FRANK & Station Frankfurt \\
FRIES & Station Friesland \\
HAM & Station Hamburg \\
HILV & Station Hilversum \\
IAFSA & In Afrikaans for South Africa \\
IDFH & In Dutch for Holland \\
IEFA & In English for Africa \\
IEFAFE & In English for Australia and the Far East \\
IEFE & In English for England \\
IEFENA & In English for England and North America \\
IEFFE & In English for the Far East \\
IEFSA & In English for South Africa \\
IEFUK & In English for the UK \\
IEFUSA & In English for the USA \\
IFFF & In French for France \\
IGFFE & In German for the Far East \\
IGFG & In German for Germany \\
\hline HES
\end{tabular}


IGFUSA In German for the United States

IPFP In Polish for Poland

ISFLA In Spanish for Latin America

LUX Radio Luxemburg

MO Mass-Observation

MoI Ministry of Information

MUN Station Munich

NBBS New British Broadcasting Station

OKW Oberkommando der Wehrmacht [German Army High Command]

PODE Station Podebrady

PRO Public Record Office

PWE Political Warfare Executive

RC Radio Caledonia

RMVP Reichsministerium für Volksaufklärung und Propaganda [German Propaganda Ministry]

RN Radio National

RRG Reichsrundfunkgesellschaft [German Broadcasting Company]

STUTT Station Stuttgart

WC Workers' Challenge

ZEE Station Zeesen 